\title{
Education for Social Responsibility: The Use of CSCL in Undergraduate Service-Learning Modules
}

\author{
Anchana Sooksomchitra, Prakob Koraneekij, Jaitip Na-Songkhla \\ Faculty of Education, Chulalongkorn University, Bangkok, Thailand \\ Email: anchana_nan@hotmail.com, onlineteacher2005@hotmail.com, jaitip.n@chula.ac.th
}

Received July 2013

\begin{abstract}
The purpose of the study was to develop an educational module for undergraduate student that effectively supports a project-based learning, and to cultivate a sense of students' social responsibility. The researcher recognizes computer-supported collaborative learning (CSCL) as a powerful tool in supporting students to share their meaningful learning activity and project. The tool can vastly and conveniently broaden the students' learning experience and facilitate different learning needs of individual student efficiently.
\end{abstract}

Keywords: Computer-Supported collaborative Learning (CSCL); Project-Based Learning; Service-Learning; Social Responsibility; Social Consciousness

\section{Introduction}

This article focuses on the development of social responsibility in students: its relevance and importance in modern day society and how to achieve it. The main duties of an educational institution are to provide the best learning environment for its students then encourage them to develop individually. To accomplish that, educators must also instill a sense of personal and social responsibility as well as prepare the students to take their place as active, responsible members of the global community who are aware of their own rights and fully respect others'.

This article mainly focuses on the urgent need of a modern day society to prepare the future citizen of a public mind who will the country to a sustainable development. One of main duties of an educational institution is to provide the best learning environment for students and encourage them to fulfill their personal social spirits. To accomplish that, educators must instill a sense of social responsibility, and prepare students to take place as active responsible members of a global community, who are aware of their own rights and fully respect others'.

Service learning is a pedagogical approach that integrates academic learning and community service. It offers an opportunity for students to have hands-on experience with in-depth knowledge; what they learn, they return back to the society. While exploring the issues and needs of a community, the students' critical thinking, planning, and problem-solving skills are enriched. This process encourages self- and independent learning which in turn makes the knowledge more applicable and meaningful to the students, enhances their sense of social responsibility, and motivates them to become a lifelong contributing and valued member of the society (Khammani, 2007).

An effective approach in this direction is through projectbased learning. In this model, students learn to actively and collaboratively research, think, organize, and come up with a practical, effective, and creative solution for a real-life situation. The method requires them to appreciate their own forte, as well as others', in order to utilize it to its best potential. It also increases their motivation to learn in addition to improving their ability to communicate and adapt to accommodate other team members (Pukiat, 2001).

To develop an educational module at the undergraduate level that effectively supports project-based learning and cultivate a sense of social responsibility in students, the researcher recognizes computer-supported collaborative learning (CSCL) as a powerful tool. CSCL is the use of computer technology to support a group of students working on a shared learning project or activity. It can vastly and conveniently broaden the students' learning experience and respond to different academic needs of each student efficiently. By incorporating the aforementioned key methods and tools into new and existing undergraduatelevel courses, educational institutions will certainly be providing students a lifelong knowledge and moral development that keeps on benefiting both themselves and the society long after the course has ended.

\section{The Theoretical Framework}

A theoretical framework is established by reviewing and examining the existing literature and studies on all four key concepts: education for social responsibility, service learning, project-based learning, and computer-supported collaborative learning (CSCL). Relevant information, variations, and theories are then analyzed to draw connections and form the basis of this study.

\section{Concept 1: Education for Social Responsibility}

A socially conscious individual values human rights and acknowledges the importance of harmonious social interaction for the developmental progress of human beings. Being socially responsible means that one is willing to help, contribute, and even make personal sacrifices for the common good. It is demonstrated through how one understands, addresses, and shows attitude towards various social issues. Common social responsibility practices include taking proper care of public property, taking actions to preserve natural resources, actively participating in social-benefit and community projects, as well as being 
constantly aware of current social situations and ready to work towards a resolution.

In Thailand, there is an ongoing effort to instill social consciousness within the society as evidenced in the National Educational Standards. An ideal Thai citizen, as a valued citizen of the country and the world, is described as a moral, intelligent, and happy person. The indicators used to identify such individual are: a good physical, mental and spiritual health; necessary life knowledge and skill sets; an ability to acquire knowledge; social skills; morality; integrity; and social responsibility (National Education Act of B.E. 2542, 1999). The National Qualifications Framework for Higher Education in Thailand also indicates that well educated graduates from a bachelor degree program should consistently demonstrate honesty and integrity, a high level of ethical and responsible behavior in academic, professional, and community environments.

Thongtiew (2003) stated that the knowledge and understanding profound enough to trigger the development of social consciousness in students must be the one that they themselves have come to realize. It cannot be taught or passed on in traditional teaching environments. This concept agrees with what Paulo Friere (1973) purposed that in order to raise consciousness, the learners must be given opportunities to think freely. Through dialogue among peers, they recognize the situation in community they belong, the reasons for it, and the possible solutions. The learners, through this process, are more involved in the real act of knowing rather than being given a ready-made view of social reality.

Many scholars have explored the connection between education and social responsibility or social consciousness (Werangkorn, 2006). Assoc. Prof. Dr. Sakchai Nirantawee, for instance, examined the Service-Learning Instructional Model used in education curriculum development within the United States. Various schools and universities have mandatory service learning programs for youth development where students actively study and assess community needs, apply their academic knowledge into resolving identified issues, then reflect on their experience to reinforce the link between their service and their learning.

Chareonwongsak (quoted in Sooksom, 2009) suggested that social consciousness development in students of all levels by integrating community-based projects into "an organized curriculum, both as mandatory programs or voluntary extracurricular activities." The subject chosen for the programs should be of public interest or yield the most impact in the broader communities, such as environmental conservation or community regulation issues. Hengjareun also proposed that students will benefit from "a wider variety of activities" that support individual learning as well as strengthen personal character and sense of social responsibility.

Social responsibility, value of human rights and harmonious social interaction, become one of the Thai Framework of National Educational Standards, and are expected to be penetrated to an educational system in such example approaches as peer collaboration and dialog with community in a situated learning environment with a project based activities.

\section{Concept 2: Service Learning}

Service learning is a pedagogical approach that provides structured opportunities for students to learn, experience, and apply their knowledge and skills in real-life situations. It re- flects a belief that good education conduces to social consciousness, and that students learn best when they can actively and purposefully get involved (Wechayant, 2001). This definition is in line with Paulo Freire's educational philosophy that calls for students to have critical attitude and take constructive action. It also corresponds to John Dewey's Educational Progressivism and Pragmatism that emphasize the importance of hands-on learning or experiential education.

The concept of experiential education, or the process that infuses direct experience with the learning environment and content, is widely applied in curriculum development across the globe. Numerous examples at all grade and levels have shown that course activities can improve students' academic achievements, and, conversely, the knowledge obtained through educational system contributes to the success of the activities and, by extension, social development. This is what service learning is about.

In the United States of America, the National and Community Service Act of 1990 became law. The legislation authorizes grants to schools to support service-learning. It also authorizes establishment of Learn and Serve America (LSA), and the National Service-Learning Clearinghouse (NSLC). Many federal agencies, non-governmental organizations, and public initiatives were born not long after, including the Iowa ServiceLearning Partnership (ISLP); Learning in Deed: Making a Difference through Service Learning (LID); and the Social Involvement through Education Service (SITES).

Across the Asian region, service-learning movements are evidenced in many countries. Central Council for Education of Japan has issued education guidelines to promote collaboration among schools, families, and communities in order to let children experience and learn in cooperation with people in local communities. In Singapore, the concept of service learning appears in the National Education policy that aims to develop national cohesion; develop the awareness of facts, circumstances and opportunities facing Singapore; and to develop a sense of emotional belonging and commitment to the community and nation. This emphasis on collaborative working mirrors the concept of "han" education system in Japan where each han (group) eats, plays, and learns together. The han members are given responsibility not just in extracurricular areas such as cleaning and serving meals, but in lessons as well. Stronger learners are expected to assist weaker members, or become banished. The entire program aims to promote equality and a sense of community. Each student comes to recognize their strength that can be utilized to benefit the group, so that when the time comes they will be able to dedicate such strength to the society and nation.

In Thailand, even though there is no official mentioning of service learning in the national policy, the importance of social responsibility and community service is ingrained into the country's education system in many forms, from elementary level through higher education. Boy- and girl-scouts as well as Thai Red Cross Youths have been mandatory activities in schools and one of the key approaches for cultivating morality and social responsibility in children. Other extracurricular activities, such as voting drive parades, are occasionally organized to meet the local community's needs. For higher education level, these activities fall into the responsibility of each university's and college's office of student affairs. Clubs are formed for those with mutual interests, many of which geared towards volunteer movements such as rural development or environment protec- 
tion.

The key principles of service learning are:

1. Service-learning projects must include academic preparation, service activities, and structured reflection by the students. This reflection should include systemic thinking about social problems as well as personal learning and reactions.

2. Service learning should engage students in meaningful work to meet real community needs. The project should also be designed to meet course objectives. The instructors must explore the community beforehand to determine the appropriate goals.

3. An academic evaluation must be performed using course objectives as indicators. The students' assessment of their own performance will be taken into consideration as well as the instructors’ (Noppakhun, 2000).

\section{Concept 3: Project-Based Learning}

A project-based learning is an educational method that puts students at the center of the learning process (Wongsuwan, 1999). According to Howard Gardner's Theory of Multiple Intelligences, the method emphasizes learning activities that are long-term, interdisciplinary. To complete a project, students must use a systematic process which often starts with a driving question that requires answering by researching, discussing, experimenting, and finally presenting the outcome (Pukiat et al., 2000). Lenschow (1998) also explained the term "project centered learning" as an education environment where students must use their analytical thinking skill to solve problems and work together towards resolutions, a process that will lead to self-development. Von and Cooper (2000) stated that as the students are more actively engaged in their learning, it gives them advantages over others in the long run.

Project-based learning, explained in Katz (1993), encourages students to question, confer, and negotiate with their teacher during the three phases of the project:

1) Beginning: Identify potential topic and driving questions

2) Investigation: Collect resources for investigating topic and find ways to resolution

3) Culmination: Reflect and share what they learn

Kats and Chard (1994) compared project based learning to the traditional learning methods and found that:

1) Projects based learning is student-driven and requires them to actively apply all existing and newly acquired knowledge and skills, as opposed to the traditional educational view of the student as a passive recipient of knowledge

2) Project based learning starts with the students' interests and progresses as they grow more engaged, as opposed to an expectation of rewards or good grades

3) In a project based classroom, students get to choose among various activities made available by their teachers, while in a traditional classroom the teachers pre-select the activities as well as all teaching materials

4) Project based learning puts teachers in the role of facilitator rather than classroom experts. It offers students choice and voice, personalizing the learning experience with teachers' guidance when needed.

5) Project based learning is not a top-down approach. The success of the course and academic achievements require constant and relentless mutual effort from both the students and teachers.

Active experiences, and investigation, preparation and pres- entation skills earned through project based learning exercises, prepare students for ongoing learning about a dynamic world. It fosters balanced, capable, adaptive citizens and problem solvers.

\section{Concept 4: Computer-Supported Collaborative Learning-CSCL}

There has been a lot of excitement about using web-based learning for higher education. Online technology can be utilized as an effective and convenient tool in supporting the development of lifelong learning skills and other emerging goals of education to meet the different demands of the students. The emphasis on student-centered learning follows the guideline and spirit of the provisions in the National Education Act of B.E. 2542 which states that educational technologies should be made accessible to students as soon as feasible so that they shall have sufficient knowledge and skills in using these technologies for acquiring knowledge themselves on a continuous lifelong basis (Ministry of Education, 2002).

Computer-Supported Collaborative Learning-CSCL stresses the importance of collaboration among the students working towards a mutual goal. It calls for skillful planning, coordination and implementation of curriculum and technology in order to achieve the goal (Barbara, 1998). Deesintum (2002) also discussed that a well-designed information technology system is a key element to the flow of information and knowledge. It assists in the learning and sharing of knowledge, helps convert tacit knowledge into explicit knowledge that can be shared, and creates a learning environment that is open for interactions and collaborations, without the limitation of time and physical location.

Koschmann (1996) conducted a research using a network of educational and information technologies as a tool to enhance collaborative learning techniques such as peer teaching, project based learning, games based learning, problem based learning, and situation based learning. The results show that the availability of CSCL provides an unprecedented opportunity to improve the quality of education and student experience.

A vast variety of CSCL tools (i.e., weblog, web board, chat/ instant messaging, and e-mail) stimulate interaction within the members of the group, especially in situations that need mutual resolution. It improves communication skills, helps forms a learning society that appreciate friendly competition for the sake of education (Panich, 2004). Such gathering of those with mutual interests, who are also willing to share knowledge and learn from each other's experiences, makes the learning process more fun. It provides a perfect forum in which a body of knowledge is formed (Sivayatorn, 2004).

\section{Conclusion}

Because young people are the ones responsible for the country's future, it is considered a main duty of educational institutions to nurture their sense of social consciousness. In order to accomplish this, it is of extreme importance for schools and universities to commit to the development and implementation of new and improved learning modules that promote self and social responsibility among students. The researcher is of an opinion that computer-supported collaborative learning (CSCL) can be used as a powerful approach for developing a servicelearning module at the undergraduate level in support of this 
concept. Such discipline can effectively structure ways for students to participate in the empowering experience of acting to make a real difference in the world.

\section{Acknowledgements}

Financial assistance was provided by the 90th anniversary of chulalongkorn university fund (Ratchadaphiseksomphot Endowment Fund).

\section{REFERENCES}

Barbara, W. (1998). Computer supported collaborative learning. An overview. Lecture notes from IVP 482, University of Bergen, Spring.

Chareonwongsak, K. (2009). Philosopher of educator. Bangkok: Success media Press.

Deesintum, K. (2002). ERP technology management for transaction in the modern age. Microcomputer Journal, December.

Freire, P. (1973). Education for critical consciousness. London: Sheed and Ward.

Khammani, T. (2007). Science of teaching: Cognitive processes in order to learn effectively. Bangkok: Chulalongkorn University Press.

Koschmann, T. (1996). CSCL: Theory and practice of an emerging paradigm. Lawrence Erlbaum.

Lenschow, R. J. (1998). From teaching to learning: A paradigm shift in engineering education and lifelong learning. European Journal of Engineering Education. http://dx.doi.org/10.1080/03043799808923494

Office of the Basic Education Commission (2002). National education act of B.E. 2542. Bangkok: Prickwan Graphics Press.

Noppakhunm, U. (2000). Lifelong learning in the 21st century. Journal of Education Studies, 28, March-June.

Panich, W. (2004). Implementation of knowledge mmanagement in organizations by the learning to fly book. Handouts, Bangkok.

Pukiat, L. et al. (2001). The teaching of the project based activities to develop students as critical. Journal of Education Studies, 28, MarchJune.

Sooksom, A. (2009). The development of public awareness to the community. Proceedings of the 2009 International Conference of the Human capital and development, Research Center, National Institute of Development Administration.

Von Kotze, A., \& Cooper, L. (2000). Exploring the transformative potential of project-based learning in university adult education. Studies in the Education of Adults.

Werangkorn, J. (2006). One of the ideas to create public awareness to students. Bangkok: Dhurakij Pundit University Press.

Wechayant, C. (2001). A development of instructional design using service learning technique for enhancing social service awareness, problem solving skill and learning achievement of lower secondary school students. Doctor of Philosophy Thesis in Curriculum and Instruction, Graduate School, Chulalongkorn University.

Wongsuwan, S. (1999) Learning for the 21st century: Learning the learner by knowledge constructionism. Bangkok: Department of Education. 